2017-08-31

\title{
Will UN Article 24 lead to the demise of special education or to its re-affirmation?
}

\section{Hyatt, C}

http://hdl.handle.net/10026.1/10140

\subsection{1/1467-9604.12170}

Support for Learning

Wiley

All content in PEARL is protected by copyright law. Author manuscripts are made available in accordance with publisher policies. Please cite only the published version using the details provided on the item record or document. In the absence of an open licence (e.g. Creative Commons), permissions for further reuse of content should be sought from the publisher or author. 
This is the author's accepted manuscript. The final published version of this work (the version of record) is published by Wiley in Support for Learning August 2017 available at: DOI

10.1111/1467-9604.12170. This work is made available online in accordance with the publisher's policies. Please refer to any applicable terms of use of the publisher.

Will UN Article 24 lead to the demise of special education or to its re-affirmation?

\author{
Christina Hyatt and Garry Hornby
}

Institute of Education, University of Plymouth

Hyatt, C. \& Hornby, G. (2017). Will UN Article 24 lead to the demise of special education or to its re-affirmation? Support for Learning, 32(3), 288-304. DOI:10.1111/14679604.12170

Keywords: inclusion, inclusive education, special education

Correspondence: Professor Garry Hornby, Institute of Education, University of Plymouth, PL4 8AA, UK. Email: garry.hornby@plymouth.ac.uk

\begin{abstract}
Article 24 of the United Nations Convention on the Rights of Persons with

Disabilities (UNCRPD) contains the first legal enshrinement of the right to inclusive education for people with disabilities. The UNCRPD maintains that children with special educational needs and disabilities (SEND) have a basic human right to be educated in mainstream schools. However, this does not take into account their moral right to be receive the education most appropriate to their needs. Therefore it is asserted by this review that implementing Article 24 may not be in the best interests
\end{abstract}


of children with SEND. Article 24 calls for all countries to implement a fully inclusive education system, thereby rendering special education provision obsolete. This article discusses the pros and cons of this possibility, including the issues and practical implications involved.

\section{Introduction}

The United Nations (UN) Convention on the Rights of Persons with Disabilities (UNCRPD) proclaims the right to inclusive education for all learners and Article 24 of this convention contains the first clear legal declaration to this effect (Broderick 2015). The UNCRPD has highlighted concerns about children with disabilities being educated in segregated settings, suggesting that they will receive a substandard education. Therefore, the UNCRPD, via General Comment Number Four of Article 24, have called for all countries to implement a fully inclusive education system (UNCRPD 2016).

As the UNCRPD is enshrined in law (Broderick, 2015) this raises questions about the future of special education and the implications of moving to, and operating, a single inclusive education system. However, in the literature on children with SEND, there is disagreement about how the concepts of inclusion, integration, segregation and exclusion are defined (Terzi, 2014). There is also no specific guidance from the UNCRPD to clarity how inclusion and inclusive education are to be realized (Cera 2015; de Beco 2016; Ssenyonjo 2016). Therefore, in this article the ideologies surrounding inclusion and special education will be discussed in relation to their positive and negative impacts on children with SEND, along with the pros and cons of the proposed move toward a fully inclusive system of education. The article incorporates a discussion regarding the human rights of people with disabilities, giving consideration to whether educating all children within mainstream schools respects the moral rights of children with SEND (Hornby 2015; Mitchell 2010).

Additionally, outcomes for children with SEND educated in mainstream settings will be examined in order to assess whether, in practice, inclusive education is as effective as its proponents maintain (Ainscow and Kaplan 2005; Avramidis et al. 2002). Finally, issues regarding inclusive education in practice, in the context of Article 24, are explored, including teacher training, teacher attitudes and the challenges associated with allocation of resources. 


\section{General Comment Number Four of Article 24}

The UNCRPD places emphasis on the role of governments in terms providing inclusive education, across all levels of the education system, for all learners (de Beco 2014). Fundamentally, in terms of disability issues, it offers a human rights dimension, replacing the medical model with the social model of disability (Kayess and French 2008). More recently, General Comment Number Four of Article 24 (UNCRPD 2016) has promoted the right to inclusive education for children with disabilities, stating that they should be able to be included in the general education system. It states that we should not see a situation in which children with SEND are excluded from free and compulsory primary and secondary education because of their disabilities. Specifically, General Comment Number Four calls for countries to begin to take measures, within the bounds of their available resources, to achieve the progressive realization of inclusive education. Under this viewpoint special and segregated education systems become outdated and obsolete. Article 24 imposes a wide-range of legal duties (Broderick 2015) on countries in terms of ensuring the availability of inclusive education (UNCRPD 2016). Nonetheless, for wealthier countries which operate a segregated education system a move to a fully inclusive system will present significant challenges (de Beco 2016) since to meet the requirements of Article 24 transformation of current education systems will be needed (de Beco 2016; Garcia et al. 2015).

\section{Defining Inclusion}

Article 24 seeks to address the marginalization of children with disabilities, through guaranteeing their right to inclusive education. Since it contains the first clear legal statement to this effect (Broderick, 2015) the idea of a single, inclusive education system cannot be disregarded. However, despite recent strides towards including children with disabilities in mainstream education, in legal terms, there is no unanimity regarding the definition of the concept of inclusive education, nor do the UNCRPD or Article 24 offer such clarity (Cera 2015; de Beco 2016; Ssenyonjo 2016). This confusion is echoed across the literature, where despite the widespread adoption of the notion of inclusion and inclusive education over the past forty years, the conceptualisation and practical implementation of these concepts has been viewed as problematic (Hegarty 2001; Hornby 2014; Lindsay 2003; Mitchell 
2010; Terzi 2014). As such, inclusion is a hotly contested area within education and definitions vary according to pedagogical, societal and policy aims (Terzi 2014).

Nutbrown et al. (2013) maintain that inclusion is the drive towards maximum participation and minimal exclusion for children with SEND in early years settings, schools, society and within the community. This fundamental ideology of inclusive education refers to the education of pupils with SEND, alongside non-disabled students, in mainstream school settings. Others, however, view education and inclusion in a broader sense, stating that it fulfills many functions within society, including giving individuals empowerment, paving the way for employment, enhancing individual quality of life and promoting equity within society (Peters 2007).

Alongside this confusion regarding how inclusion is defined, there is some uncertainty surrounding exactly who inclusive education encompasses. From the point of view of teachers and policy makers inclusion has been primarily focused on individuals with special educational needs, behaviour problems and those with disabilities. In contrast, other groups view inclusion in a broader sense, as being concerned with inequalities for children not only with SEND, but also gender, race, social background and attainment issues (NASUWT 2008). As a consequence, others in the field argue that inclusion encompasses more than children with SEND by seeking to embrace pupils who are at risk of exclusion or marginalization for whatever reason (Ainscow et al. 2006). On this premise inclusion becomes an issue of social justice (Ballard 2003) and can be described as a concept which seeks to address barriers to learning and participation with a view to providing resources which support the learning and participation of all children (Ainscow et al. 2006). From this standpoint, inclusive education can be seen as a transformational process, transforming institutions, communities and society, to enable them to become more sensitive to diversity (Arnesen et al. 2009).

Initially, ideas about inclusion were used as a means to understand and overcome deficits (Donnelly 2010). Now it is clear that current definitions of inclusion are much more extensive and encompass issues of human rights, social justice, gender, ethnicity, class and health, alongside issues relating to access, involvement, achievement and participation (Ouane 2008). In order for countries to move forward with the aims of the UNCRPD, clear definitions 
of inclusion and inclusive education are needed in order to clarify implications for educational policy and practice (Hornby 2012; Hornby 2014). Nevertheless, where definitions are constructed on an individual country basis it is considered that a 'one size fits all' approach will not suit every country as the definition and implementation of inclusive education will be dependent on each country's social, economic, political, cultural and historical make-up (Mitchell 2005).

\section{Integration and inclusion, segregation and exclusion.}

Across the discourse relating to inclusion, educationalists have been debating the benefits of 'integration' over 'segregation' for pupils with SEND for decades. Concerns have emerged regarding the inclusion of pupils with SEND and how this may impact on schools' effectiveness, with Gerber (1996) maintaining that, as SEND pupils do not tend to excel academically, schools may appear to be underperforming in league tables. However, this view is not shared by all, and proponents of inclusion assert that the incorporation of inclusive practices could in fact reduce the number of children requiring special education (Ashby 2012), or in some cases, could even lead to the prevention of the development of disabilities (Fletcher and Vaughn 2009). It is also maintained by inclusionists that inclusive education improves the quality of life of pupils with SEND as well as increasing educational performance (Reed et al. 2011). Nevertheless, inclusion needs to go further than simply integrating children with SEND into mainstream classrooms and this is recognized by the UNCRPD, which asserts that: “...integration does not automatically guarantee the transition from segregation to inclusion." (UNCRPD 2016, 4).

This view is echoed across the discourse relating to inclusion, with proponents maintaining that educating pupils with SEND in mainstream schools should not only be about offering increased opportunities to interact with typically developing children (Avramidis and Wilde 2009) but also confirming that schools have a broader role to play in terms of shaping children's life chances and imprinting society's values upon learners (Lewis et al. 2005). On this basis, schools should operate as not only educational facilities, but also as agents of change (Barton 1986), in which the school environment becomes a place where inequality and discrimination can be eliminated (Lloyd 2000).

Conversely, however, it has been clearly evidenced that children with SEND, 
who are educated in the mainstream, have a lower social status in comparison to their classmates (Avramidis and Wilde 2009; Larrivee and Horne 1991; Pavri and Luftig 2000). Also, research suggests that many children with SEND lack the necessary social skills for successful interaction, leading to some children being bullied (Humphrey and Hebron 2015) and/or becoming socially isolated from their peers (Avramidis 2009). Thus, whilst it is suggested that inclusive education has positive social benefits for children with SEND, it appears that this is not always the case when there is a disparity between the social skills of children with SEND in comparison to their peers (Humphrey and Hebron 2015).

\section{Inclusion and the Rights of the Child}

Irrespective of the confusion regarding the definitions of inclusion, it is clear from the UNCRPD (2016) what inclusive education is not. It is not equivalent to education in special schools and neither is it equal to integration into mainstream schools (de Beco 2016; Cera 2015). However, many researchers and educationalists argue that such a conceptualization of inclusive education is fundamentally flawed, with the NASWT (2009) going as far as describing such full inclusion as being tantamount to a 'form of child abuse'. Others in opposition to full inclusion also point out the practical difficulties related to offering the same education to such a diverse group of students, with such a wide variety of learning needs (Feiler and Gibson 2003; Hornby 1999; MacBeath et al. 2006; Wapling 2016). Thus, there are questions as to whether all children should be educated within the general education system, and whether for a small minority of children inclusive education is actually achievable (de Beco 2014).

Article 24 promotes inclusion as being a basic human right of children with disabilities (UNCRPD 2016) but under further scrutiny this standpoint appears to be somewhat idealistic, with opponents arguing that inclusion in mainstream classrooms may not be the most appropriate option in all cases, as it does not take into account children's moral rights (Hornby 2012; Hornby 2015; Mitchell 2010). To clarify the confusion between human rights and moral rights, just because someone has a human right to a certain option doesn't mean that it is morally the right thing course of action for them (Thomson 1990). Thus, although their human rights allow children with SEND to be educated alongside their mainstream peers, for some of them this may not, morally, be the right or best option. As Warnock puts it, "What is a manifest good in society, and what it is my right to have... may not be what is best for 
me as a schoolchild" (quoted in Terzi 2010, p. 36). Therefore, despite the good intentions rooted in full inclusion, this option may in fact disadvantage some of the children it seeks to help (Ainscow and Haile-Giorgis 1998; Hornby 2014).

The inclusion of pupils with SEND has been discussed at length by Shaddock (2006) who maintains that parts of the curriculum taught in classrooms may not be a priority for all children with SEND to learn, particularly where a substantial gap in academic levels exists between SEND pupils and their peers. This view is also supported by Farrell (2010), who asserts that special education programmes should be differentiated from the normal curriculum so they are appropriate for pupils with SEND. This is because priorities for some pupils, with more severe levels of SEND, are very different from those of typically developing children.

Apparently, during draft meetings, the question of whether children with disabilities have the right to opt for special schooling was discussed during the negotiations, but as the final version of Article 24 reveals, this perspective was rejected (de Beko 2016) which in part, may be due to a lack of input from special education experts (Bakken and Oblakor 2016). In the past, opponents have expressed reservations about the ideology of inclusive education, with Bailey (1998) stating that inclusion should not be a "fervent crusade (to promote) inclusive schooling." (p. 45). Many academics support this standpoint, arguing that special school provision has a place within the education system for some children (Cera 2015; Farrell 2000; Hornby 2002; Hornby 2014; Lindsay 2007; Terzi 2010). In practical terms, Hornby (2014) maintains that whilst the needs of many children with high levels of SEND may be met in mainstream schools during the initial years of primary education, by the time of middle or high school, the demands of the curriculum become too great for some of these children.

Furthermore, Lindsay (2007) asserts that the empirical evidence underpinning inclusion is controversial and instead believes that children should receive an education which is appropriate, and suited to, their individual needs. Whilst inarguably, the principles promoted by inclusionists set the scene for a more tolerant and permissive society, it has been increasingly recognized that the ideal of full inclusion, with all children being educated within the mainstream, is not feasible (Hornby 2015). Respected educationalists such as Baroness Warnock have cast doubts over the concept of inclusion being about all children "under the same roof" (in Terzi 2010, 156) and she has been openly critical 
of how inclusion has been translated into practice, stating: "... there is increasing evidence that the ideal of inclusion, if this means that all but those with the most severe disabilities will be in mainstream schools, is not working" (Warnock 2005, 32).

Correspondingly, studies have highlighted that many mainstream teachers are skeptical about the practical implementation of inclusion at the classroom level (Avramidis and Norwich 2002; Pijl et al. 2011; Ring 2005) and it appears that the United Kingdom (UK) government also have doubts about the suitability of inclusion in all cases, as they were the only government to have previously placed a formal reservation against Article 24. This stated that, "(the UK reserves) the right for disabled children to be educated outside their local community where more appropriate education provision is available elsewhere..." (Bakken and Oblakor 2016, 168).

As such, the question remains as to whether all children should have to participate in the general education system as Article 24 requires. Opponents would of course argue that there are a small number of children for whom reasonable accommodations are not possible, or the support measures are inadequate (de Beco 2014). Thus, whilst the philosophy of inclusion may champion disabled children's human rights, it may not necessarily respect individual needs and choices (Hornby 2014). For example, research into the education of deaf/hard of hearing learners in Northern Ireland and Sweden has shown these children struggle in oral-based education systems, and in this instance, the best environment appropriate to their needs is the special school (Doherty 2012). Inclusionists assert that there are benefits of inclusive education for this population, including: social interaction and contact with peers with normal hearing, social acceptance by hearing peers, and access to typical behavioural and linguistic models of hearing (Eriks-Brophy et al. 2012; Xie et al. 2014). Nonetheless, it has been evidenced that integrating children who are deaf/hard of hearing into mainstream classrooms has not necessarily facilitated acceptance by peers, aided meaningful social interaction, nor has it given deaf/hearing of hearing students a sense of inclusion (Bobzien et al. 2013; Weisel et al. 2005; Xie et al. 2014). This has led to some writers arguing that full inclusion in mainstream settings cannot be achieved for deaf learners, due to their specific difficulties with communication and comprehension (Peters 2002). So in some cases, it is clear that inclusive education 
may not always meet the needs of individuals with SEND, and as such it cannot be morally right to educate these children within the general education system (Hornby 2012). Rights, and the promotion and protection of these, are at the heart of Article 24 (UNCRPD 2016), however, if individual needs are not being met, then logically it could be argued that the key rights of children with SEND are not being fulfilled, fundamentally undermining the rationale behind Article 24 .

\section{Inclusive Education Outcomes}

The UNCRPD expressed concerns about children with disabilities receiving an education in settings where they are segregated from their peers, stating they would "receive an inferior quality of provision" (UNCRPD 2016, 2). In support of this ideology and the aims of Article 24, are positive examples where inclusive education has been implemented. For example, an in-depth case study of inclusive school practice took place in the South West of England, where all pupils participated in mainstream school life and students with SEND were included in all class activities (Avramidis et al. 2002).

Overall, the study reported several beneficial results, in particular respondents were positive about attitudes towards inclusion and the extent to which the school ethos could be viewed as inclusive. Students appeared to benefit academically, and teachers achieved a sense of personal satisfaction in terms of implementing inclusive practice (Avramidis et al. 2002). A further example of a school viewed as successful in terms of inclusion is a secondary school in the North of England. Qualitative research from Ainscow and Kaplan (2005) recorded the views of pupils attending the school. Overall, students were positive about inclusive practices and the school itself and this was supported by views from teaching staff and the records of academic grades achieved. Interestingly, teacher attitudes were highlighted as an issue and students felt it was difficult to outlive a bad reputation, despite pupils improving both their academic performance and changing their behaviour

Whilst the above findings report successful outcomes for inclusion, this has not always been the case. A follow up study conducted by Hornby and Kidd (2001) investigated the outcome of an inclusion project for twenty-nine students with moderate learning difficulties, who were transferred from a special schools to mainstream provision for the last few years of their school lives. Worryingly, high 
levels of unemployment were reported amongst respondents and the vast majority still lived at home with their parents. Overall, the study revealed that whilst students may have been included in mainstream schools towards the end their school lives, this did not ensure they would not be excluded from mainstream society as adults (Hornby and Kidd 2001). These findings offer contradictory evidence to past assertions, of poorer outcomes for children educated in special schools (Lipsky and Gartner 1992).

From the literature, it appears that inclusive education generates mixed results. Recent research into effective inclusive classroom practices found that outcomes, both in terms of attainment and attitudes towards social integration for children with SEND in the mainstream, were varied (Sakarneh and Nair, 2014). Additionally, a large systematic literature review into inclusion in low and middle income countries, once again found no definitive evidence to underpin the idea of better educational outcomes for children with SEND in inclusive classrooms (Wapling, 2016). These findings offer support to previous empirical research, which reported a lack of evidence to promote inclusive education in mainstream classrooms (Lindsay, 2007). This suggests that, on balance, inclusive education may not be as beneficial as has been suggested. Furthermore, it is contended by Hornby (2014) that the most important outcome for people with SEND is not necessarily inclusion within mainstream classrooms, but inclusion within their communities once they have finished school.

\section{Implementing Inclusive Education in Practice}

It is proposed that, for an inclusive environment to be realized in practice, there is a need for specialized curricula and help from special school teachers (Hornby and Kidd 2001). Hornby (2014) offers an argument for the reconceptualization of the concepts of inclusive education and special education to form inclusive special education. He maintains that, whilst the concepts of inclusion and special education may appear to be diametrically opposed, as they have developed in response to differing demands, and with different philosophies, they can be synthesized, with a view to achieving the highest level of post-education inclusion in society for young people with SEND (Hornby 2014). Whilst this reformation of education may go someway toward alleviating the practical problems that countries with partly segregated education systems may experience if a fully inclusive system is developed, it is difficult to see how all special schools can be closed, since doing so would 
marginalize some children with disabilities by denying them an appropriate education (Cera 2015). Additionally, integrating students with SEND into mainstream classes would also not achieve the desired outcome, since integration is not seen to be equal to inclusion by the UNCRPD (2016).

In practical terms, if the aims of Article 24 are realized and specialist curricula and teachers are not transferred to mainstream settings, the responsibility for teaching children with SEND would fall to mainstream teachers and support staff. Therefore, a critical aspect to be addressed would be adequate and appropriate teacher training (de Beco 2016). However, in the literature teacher training (or lack thereof), is cited as one of the principal barriers to inclusion (Florian 2008; Forlin 2001; Hart et al. 2004; Simmons and Bayliss 2007) and research has highlighted how teachers in mainstream settings have struggled to meet the needs of students with severe or complex SEND (Simmons and Bayliss 2007). Hornby (2014) acknowledges that many teachers do not feel competent to teach all children and this may in part be due to a lack of knowledge about SEND (Hartley 2010; Hornby 2014). It is therefore clear that radical changes in teacher education would need to take place, in order to provide effective training and support for mainstream class teachers.

Article 24 recognizes the need for highly trained staff stating that, "All teachers and other staff (are to) receive education and training, giving them the core values and competencies to accommodate inclusive learning environments..". (UNCRPD, 2016, 5). Even so, in the past Warnock (2005) has highlighted that the teaching of SEND children in mainstream settings has largely been carried out by teaching assistants. Thus, if special schools closed and mainstream teachers did not receive additional training, we would continue to see teachers in mainstream settings struggle to meet the needs of children with complex needs (Simmons and Bayliss 2007). To this end, Hornby (2014), does not advocate the abolition of special education provisions, as he maintains that special schools have a place within future education systems, providing support and guidance to mainstream schools and through educating children with severe levels of SEND. This is because teachers in mainstream settings, as opposed to teachers in special schools, may not be able to meet such a wide variety of needs (Hornby 2015). This structure, however would not be possible, if special schools and classes become obsolete under the provisions of Article 24.

For countries to move towards fully implementing Article 24, at classroom 
and school levels, certain conditions would need to underpin inclusive education for students with SEND, including teachers possessing specific knowledge and skills (Tilstone et al.1998). Knowledge about the different types and features of children with SEND and the skills required for implementing evidence-based strategies for effectively teaching them are essential to successful inclusive education (Hornby 2014). There would also need to be a positive reframing of teachers' attitudes about pupils' abilities and about their own professional practice, since developing successful inclusive practice is also about teachers considering their own attitudes, values and beliefs (Black-Hawkins et al. 2008; Rouse 2007). This is because the way inclusion is translated into practice depends not only on practitioners' understanding of inclusion, but also on their personal beliefs as well as their values and attitudes toward pupils with SEND (Avramadis et al. 2000). Alongside changes in teachers' attitudes, knowledge and skills, having a positive school ethos and developing quality support networks has been found to be necessary in order to facilitate inclusive education (Ainscow 1995; Shaffner and Buswell 1996). The school environment should be one that fosters acceptance and celebration of diversity to ensure that pupils with SEND feel valued and part of the school community.

Alongside obstacles relating to training and the changing of attitudes there are more practical challenges which would need to be met if Article 24 was to be fully implemented. These include providing medical care and specialist equipment (UNCRPD 2016) and the associated costs of providing those resources. In the past, this has been underlined as a key factor which has constrained attempts to successfully implement inclusion, as budgetary cuts have led to a shortage of professionals such as speech and language therapists and educational psychologists in mainstream settings (National Union of Teachers 2003).

Nevertheless, arguments against inclusion on the grounds of resources are thought to be false (de Beco 2016) as an inclusive education system is considered to be more cost effective than a segregated system (Salamanca Statement 1994). This idea, however is not currently supported by the literature which indicates there is no empirical evidence to suggest inclusive education is a more cost effective approach (Urwick and Elliott 2010). Consequently, this presents concerns, as it has been evidenced that teachers cannot meet the needs of SEND children without specialist resources and appropriate services (Hornby 2014; Wapling 2016). On a more mundane 
level, there are also problems surrounding time as a resource, as inclusion has been shown to negatively impact on teacher workload, leaving little time to prepare individual resources for children with SEND (McBeath et al. 2006) and inevitably adding stress to teachers working lives.

\section{Conclusion}

As the provisions of Article 24 are legally binding (Broderick, 2015), a move to progressively realize a fully inclusive education system is a reality that cannot be dismissed. The UNCRPD proclaims the right to inclusive education for children with disabilities (UNCRPD 2016), however there is currently no consensus either from the UNCRPD, nor in the literature as to exactly what the concept of inclusion means (Cera 2015; de Beco 2016; Ssenyonjo 2016). Additionally, it is also unclear exactly who inclusion encompasses (Ainscow et al. 2006, NASUWT 2008). Despite this confusion, it is plain that current definitions of inclusion encompass human rights and social justice issues (Ouane 2008). Whilst there is currently no formal definition offered by the UNCRPD, it is explicit that segregated education, in special schools, is not considered to be compatible with inclusive education (de Beco 2016; Cera 2015).

Proponents of inclusion maintain that it increases quality of life and improves educational performance (Reed et al. 2011) and that inclusive mainstream schools can shape children's life chances (Lewis et al. 2005). Nonetheless, this is not always the case since research has shown that some SEND children can become socially isolated from their peers when in inclusive settings (Avramidis 2009). Therefore, whilst the principles of inclusion might set the scene for a more permissive and accepting society, there are questions surrounding whether all children should be educated in mainstream settings and whether inclusion is achievable for all children (de Beco 2014). Article 24 champions inclusion as being a basic human right of children with disabilities (UNCRPD 2016) but critics would argue that full inclusion does not take in to account the moral rights, or choices, of the child and it is therefore not the most appropriate option in all cases (Hornby 2012; Hornby 2015; Mitchell 2010). Consequently, it is asserted that implementation of Article 24 will not lead to a situation in which all children with SEND will receive an optimal education.

In practice there are practical issues related to a fully inclusive education system being realized (de Beco 2016), in particular relating to resources, as whilst it is cited inclusive education is a more cost effective approach (Salamanca Statement, 
1994), empirical evidence does not support this notion (Urwick and Elliott 2010). If a move is made to achieve the aims of Article 24, issues also abound in terms of who will teach SEND pupils, as it has been evidenced that teachers in mainstream settings have struggled to meet the needs of all pupils (Simmons and Bayliss 2007) and inadequate teacher training has been cited as a principal barrier to inclusion (Forlin 2001; Hart et al. 2004; Simmons and Bayliss 2007; Florian 2008).

A solution offered by Hornby (2014) is the concept of inclusive special education, which would see specialist teachers and curricula transferred from special schools into mainstream settings with special schools offering support and guidance to mainstream schools, whilst also providing for the needs of children with the most severe levels of SEND. However, as Article 24 is very clear regarding its stance on segregated schools and classes (UNCRPD 2016), it therefore remains to be seen what the future of special education will be and how this will be translated into practice. It could well be that the challenges encountered in attempting to implement article 24 will lead to a re-affirmation of special education in meeting the needs of children with SEND.

\section{References:}

Ainscow, M. 1995. "Special needs through school improvement: school improvement through special needs". In Towards inclusive schools? edited by C. Clark, A. Dyson and A. Millward, 63-77. London: David Fulton.

Ainscow, M., and I. Kaplan. 2005. "Using Evidence to Encourage Inclusive School Development: Possibilities and Challenges." Australasian Journal of Special Education 29 (2): 106-116.

Ainscow, M., T. Booth, and A. Dyson. 2006. "Inclusion and the standards agenda: negotiating policy pressures in England”. International Journal of Inclusive Education, 10 (4-5): 295-308.

Ainscow, M. and M. Haile-Giorgis. 1998. The Education of Children with Special Needs: Barriers and Opportunities in Central and Eastern Europe. Innocenti Occasional Papers (67). Paris: UNICEF. 
Arnesen, A., J. Allen, and E. Simonsen. (eds.) 2009. Policies and Practices for teaching socio-cultural diversity. Concepts, principles and challenges in teacher education. Strasbourg: Council of Europe.

Ashby, C. 2012. "Disability studies and inclusive teacher preparation: A socially just path for teacher education." Research and Practice for Persons with Severe Disabilities 37 (2): 88-99.

Avramidis, E., P. Bayliss, and R. L. Burden. 2000. "Student teachers' attitudes towards the inclusion of children with special educational needs in the ordinary school. Teaching and Teacher Education 16 (3): 277-93.

Avramidis, E., P. Bayliss, and R. L. Burden. 2002. "Inclusion in action: an in depth case study of an effective inclusive secondary school in the south-west of England.” International Journal of Inclusive Education 6 (2): 143-163.

Avramidis, E., and A. Wilde. 2009. "Evaluating the social impacts of inclusion through a multi-method research design.” Education 3 to 1337 (4): 323-334.

Bailey, J. 1998. Australia: Inclusion through categorisation. In From them to us: An international study of inclusion in education, edited by T. Booth, and M. Ainscow, 186-192. London: Routledge.

Bakken, J., and E. Obiakor. 2016. General and Special Education Inclusion in an Age of Change: Roles of Professionals Involved. Bingley, England: Emerald.

Ballard, K. 2003. "The analysis of context: Some thoughts on teacher education, culture, colonization and inequality." In Developing inclusive teacher education T. Booth, K. Nes, and M. Stromstad. London: Routledge/Falmer.

Barton, L. 1997. “The politics of special educational needs. In Disability Studies: Past, Present and Future, edited by L. Barton, and M. Oliver, M., 138-159. Leeds: The Disability Press. 
Black-Hawkins, K., L. Florian, and M. Rouse. 2008. "Achievement and Inclusion in Schools and Classrooms: Participation and Pedagogy.” In: British Educational Research Association Conference, September 2008. Available at: http://www.leeds.ac.uk/educol/documents/178012.pdf (Accessed 12 Dec. 2016).

Bobzien, J., C. Richels, S.A. Raver, P. Hester, E. Browing, and L. Morin. 2013. "An observational study of social communication skills in eight preschoolers with and without hearing loss during cooperative play." Early Childhood Educational Journal 41: 339-346.

Broderick, A. 2015. "The long and winding road to equality and inclusion for persons with disabilities: the United Nations Convention on the Rights of Persons with Disabilities.” Unpublished Ph.D Dissertation. Netherlands: Maastricht University.

Cara, M. 2013. "Academic and social outcomes of children with SEN in the general education classroom.” Journal of Educational and Social Research 3(7): 9099.

Cera, R. 2015. "Protecting the rights of people with autism in the fields of education and employment." In National Legislations on Inclusive Education and Special Educational Needs of People with Autism in the Perspective of Article 24 of the UNCRPD, edited by V. Della Fina and A. Cera, 79-108. Heidelberg, Germany: Springer.

Convention on the Rights of Persons with Disabilities. (2006). United Nations. Available at:

http://www.un.org/disabilities/convention/conventionfull.shtml [Accessed 15th November 2016]

Davis, J. M., and N. Watson. 2001. "Where are the Children's Experiences? Analysing Social and Cultural Exclusion in "Special" and "Mainstream" Schools." Disability and Society 16 (5): 671-687. 
de Beco, G. 2014. "The Right to Inclusive Education According to Article 24 of the UN Convention on the Rights of Persons with Disabilities: Background, Requirements and (Remaining) Questions." Netherlands Quarterly of Human Rights 32: 263-287.

de Beco, G. 2016. "Transition to Inclusive Education Systems According to the Convention on the Rights of Persons with Disabilities". Nordic Journal of Human Rights 34(1): 40-59.

Donnelly, V. 2010. Teacher Education for Inclusion: International Literature Review. Odense, Denmark: European Agency for Development in Special Needs Education.

Doherty, M. 2012. "Inclusion and Deaf education: The Perceptions and Experiences of Young Deaf People in Northern Ireland and Sweden.” International Journal of Inclusive Education 16 (8):791-807.

Eriks-Brophy, A., A. Durieux-Smith, J. Olds, E. M.Fitzpatrick, C. Duquette and, J. Whittingham. 2012. "Communication, Academic, and Social Skills of Young Adults with Hearing Loss." The Volta Review 112: 5-35.

Farrell, P. 2000. "The impact of research on developments in inclusive education." International Journal of Inclusive Education 4: 153-162.

Farrell, M. 2010. Debating Special Education. Abingdon, England:

Routledge.

Feiler, A., and H. Gibson. 2003. "Threats to the Inclusive Movement". British Journal of Special Education 26 (3): 147-152.

Fletcher, J., and S. Vaughn. 2009. "Response to Intervention: Preventing and Remediating Academic Difficulties.” Child Development Perspectives 3 (1): 30-37.

Florian L. 2008. "Special and Inclusive Education: Future Trends." British Journal of Special Education Needs 35 (4): 202-208. 
Forlin, C. 2001. "Inclusion: Identifying Potential Stressors for Regular Class Teachers." Journal of Educational Research 43(3): 235-245.

Garcia-Iriarte, E., R. McConkey, and R. Gilligan. 2015. Disability and Human Rights. London: Palgrave.

Gerber, M. 1996. "Reforming special education: Beyond inclusion.” In Disability and the Dilemmas of Education and Justice, edited by C. Christensen and F. Rizvi, 156174, Philadelphia: Open University Press.

Hart, S., A. Dixon, M. J. Drummond, and D. McIntyre. 2004. Learning

Without Limits. Maidenhead: Open University Press.

Hartley, R. 2010. Special Educational Needs: Reforming Provision in English Schools. London: Policy Exchange.

Hegarty, S. 2001. "Inclusive education: a case to answer." Journal of Moral Education 30 (3): 243-249.

Hornby, G. 1999. "Inclusion or Delusion: Can One Size Fit All?" Support for Learning 14 (4): 152-157.

Hornby, G. 2002. “Promoting Responsible Inclusion: Quality Education for All.' In Enabling Inclusion: Blue Skies - Dark Clouds? Edited by T. O’Brien, 3-19, London: Stationary Office.

Hornby, G. 2012. "Inclusive Education for Children with Special Education Needs: A Critique of Policy and Practice in New Zealand.” Journal of International Comparative Education 1 (1): 52-60.

Hornby, G. 2014. Inclusive Special Education: Evidence-Based Practices for Children with Special Needs and Disabilities. New York: Springer. 
Hornby, G. 2015. "Inclusive Special Education: Development of a New Theory for the Education of Children with Special Educational Needs and Disabilities." British Journal of Special Education 42 (3): 234-256.

Hornby, G., and R. Kidd. 2001. "Transfer from Special to Mainstream - Ten Years Later.” British Journal of Special Education 28 (1): 10-17.

Humphrey, N. and J. Hebron. 2015. "Bullying of Children and Adolescents with Autism Spectrum Conditions: A 'State of the Field' Review.” International Journal of Inclusive Education 19 (8): 845-862.

Kayess, R., and P. French. 2008. "Out of the Darkness into Light? Introducing the Convention on the Rights of Persons with Disabilities." Human Rights Law Review 8 (1): 1-34.

Larrivee, B. and M. Horne. 1991. "Social Status: A Comparison of Mainstreamed Students with Peers of Different Ability Levels." The Journal of Special Education, 25 (1): 90-101.

Lewis, A., C. Robertson., and S. Parsons. 2005. Experiences of Disabled Students and their Families: Phase 1. DRC Research Report. Manchester, England: Disability Rights Commission.

Lindsay, G. 2003. "Inclusive Education: A Critical Perspective.” British Journal of Special Education, 30 (1): 3-12.

Lindsay, G. 2007. "Educational Psychology and the Effectiveness of Inclusive Education/Mainstreaming.” British Journal of Educational Psychology, 77: 1-24.

Lipsky, D.K., and A. Gartner. 1992. "Achieving Full inclusion: Placing the Student at the Center of Educational Reform." In Controversial Issues Confronting Special Education edited by W. Stainback and S. Stainback, 3-12. Boston, MA: Allyn and Bacon. 
Lloyd, C. 2000. "Excellence for All Children - False Promises! The Failure of Current Policy for Inclusive Education and Implications for Schooling in the 21st Century”. International Journal of Inclusive Education, 4 (2): 133-152.

MacBeath, J., M. Galton, S. Steward, A. MacBeath, and C. Page. 2006.

The Cost of Inclusion. Cambridge: Victoire Press.

Mitchell, D. (ed.) 2005. Contextualizing Inclusive Education: Evaluating Old and New International Perspectives. Abingdon, England: Routledge.

Mitchell, D. 2010. Education that Fits: Review of International Trends in the Education of Students with Special Educational Needs. Wellington, New Zealand: Ministry of Education.

NASUWT 2008. Special Educational Needs and Inclusion: Reflection and Renewal, Birmingham, England: Clarkeprint.

NASUWT 2009. 'NASUWT Calls for a Fit for Purpose, National Definition of Inclusion.' Available at: http://www.epolitix.com/stakeholder-websites/pressreleases/ press-release- details/newsarticle/nasuwt-calls-for-a-fit-for-purposenationaldefinition-of- inclusion-2///sites/nasuwt/ (Accessed: 5 December 2016).

National Union of Teachers 2003. Special Educational Needs Co-ordinators and the Revised Code of Practice: An NUT Survey, London: NUT.

Norwich, B. 2007. Dilemmas of Difference, Inclusion and Disability: International Perspectives and Future Directions. London: Routledge.

Nutbrown, C., P. Clough, and F. Atherton. 2013. Inclusion in the Early Years, London: SAGE.

Ouane, A. 2008. Creating education systems which offer opportunities for 
lifelong learning. Paper presented at UNESCO International Conference on Education 'Inclusive education: the way of the future' 48th session. Geneva, 25-28 November 2008. Available at:http://www.ibe.unesco.org/fileadmin/user_upload/Policy_Dialogue/48th_ICE /CONFINTED_48_Inf_2_English.pdf (Accessed: 3rd January 2017)

Pavri, S. and R. Luftig. 2000. "The Social Face of Inclusive Education: Are Students with LD Really Included in the Classroom?" Preventing School Failure, 45 (1): 8-14.

Peters S. 2002. "Inclusive Education in Accelerated and Professional Development Schools: A Case-based Study of Two School Reforms in the USA." International Journal of Inclusive Education, 6: 287-308.

Peters S. 2007. "Education for All?: A historical Analysis of International Inclusive Education Policy and Individuals with Disability.” Journal of Disability Policy Studies, 18(2):98-108.

Reed, P., L. Osborne, and E. Waddington. 2011. "A Comparative Study of the Impact of Mainstream and Special School Placement on the Behaviour of Children with Autism Spectrum Disorders.” British Educational Research Journal, 38 (5): 749-763.

Rouse, M. 2008. "Developing Inclusive Practice: A Role for Teachers and Teacher Education?" Education in the North, 16. Accessed from https://www.abdn.ac.uk/eitn/journal/46/

Sakarneh, M., and N. Nair. 2014. "Effective Teaching in Inclusive Classroom: Literature Review.” Journal of Education and Practice, 5 (24): 28.34.

Shaddock, T. 2006. "Students with Disabilities in the Mainstream: What Works for Teachers and Students?.” Proceedings of the CHERI Conference, pp.15-18, September 2006, Westmead Hospital, New South Wales, Australia. 
Shaffner, C., and B. Buswell. 1996. "Ten Critical Elements for Creating Inclusive and Effective School Communities." In Inclusion: A Guide for Educators edited by S. Stainback and W.Stainback. Baltimore, MD: Paul H. Brooks.

Simmons B., and P. Bayliss. 2007. "The Role of Special Schools for Children with Profound and Multiple Learning Difficulties: Is Segregation Always Best?” British Journal of Special Education, 34 (1): 19-24.

Ssenyonjo, M. 2016. Economic, Social and Cultural Rights in International Law. (2nd edition). Oxford: Hart.

Terzi, L. (ed.) 2010. Special Educational Needs: A New Look. London, Continuum.

Terzi, L. (2014). "Reframing Inclusive Education: Educational Equality as Capability Equality.” Cambridge Journal of Education, 44 (4): 479-493.

Thomas, G., and A. Loxley. 2007. Deconstructing Special Education and Constructing Inclusion (second edition). Maidenhead, England: Open University Press.

Thomson, J. J. 1990. The Realm of Rights. Cambridge, MA: Harvard University Press.

Tilstone, C., L. Florian, and R. Rose. 1998. Promoting Inclusive Practice. London: Routledge.

UNESCO (1994). The Salamanca Statement and Framework for Action on Special Needs Education. Salamanca, Spain: UNESCO.

United Nations Convention on the Rights of Persons with Disabilities. 2016. "General Comment No. 4 - Article 24: Right to Inclusive Education.” Accessed 2nd December 2016, from: http://www.refworld.org/docid/57c977e34.html 
Urwick, J., and J. Elliott. 2010. "International Orthodoxy Versus National Realities: Inclusive Schooling and the Education of Children with Disabilities in Lesotho." Journal of Comparative Education, 46: 137-150.

Wapling, L. 2016. Inclusive Education and Children with Disabilities: Quality Education for All in Low and Middle income Countries. CBM. Accessed on http://www.cbm.org/article/downloads/54741/Quality_Education_for_All_LMIC_Evi dence_Review_CBM_2016_Full_Report.pdf

Warnock, M. 2005. Special Educational Needs: A New Look. London: Philosophy of Education Society of Great Britain.

Weisel, A., T. Most, and C. Efron. 2005. "Initiations of Social Interactions by Young Hearing Impaired Preschoolers." Journal of Deaf Studies and Deaf Education, 10: $161-170$.

Xie, Y., M. Potm, and B. Peters. 2014. "Children Who Are Deaf or Hard of Hearing in Inclusive Educational Settings: A Literature Review on Interactions With Peers." Journal of Deaf Studies and Deaf Education, 19 (4): 423-437. 